www.jmscr.igmpublication.org

Index Copernicus Value: 79.54

ISSN (e)-2347-176x ISSN (p) 2455-0450

crossrefDOI: https://dx.doi.org/10.18535/jmscr/v7i3.102

\title{
Ayurvedic Management of Chronic Inflammatory Demyelinating Polyneuropathy: A Case Study
}

\author{
Authors \\ Dr Sarita Sonale Alias, Dr Sarita Gaikwad \\ M.D., Ph.D. (Kayachikitsa) \\ Retd. Assistant Director, AYUSH, Pune Region, Pune. (Maharashtra state, India) and \\ Ex. HoD, Ayurved Research Department, Sassoon General Hospitals, Pune, India \\ Email: sarita.pgaikwad@gmail.com, Mob: 9822025105
}

\begin{abstract}
Chronic Inflammatory Demyelinating Polyneuropathy (CIDP) is a rare, progressive or relapsing neuromuscular disorder with chronicity of more than 8 weeks, manifesting in to bilaterally symmetrical proximal and distal weakness of muscles of extremities, tingling, numbness, fatigue, gait imbalance with loss of deep tendon reflexes. It is also termed as an Auto immune disorder for which no specific and effective treatment is available, though Plasmapheresis, steroid therapy, immunotherapy, stem cell therapy, etc. have been tried with variable success rates. Here is a case study that was treated by Modern medicine by steroids and Plasmapheresis for more than 2 months with no improvement but case was only deteriorated. Such case came to Ayurvedic Research ward, Sassoon General Hospital in bed ridden state. With initiation of Ayurvedic treatment, there was marked improvement in his condition, and the bed ridden patient began to walk. This case study showed a ray of hope to thousands of such poor sufferers of C.I.D.P., that Ayurved has potential and strength to effectively treat this progressive neurological disorder.

Keywords: Chronic Inflammatory Demyelinating Polyneuropathy (C.I.D.P.), Guillain Barre Syndrome, Auto immune disease, Ayurvedic management, Aam-vat vyadhi.
\end{abstract}

\section{Introduction}

Chronic Inflammatory Demyelinating Polyneuropathy (C.I.D.P.) is a rare, progressive neurological disorder that targets the myelin sheath of nerve fibres and nerve roots by causing inflammation ${ }^{1}$. This slows down the ability of nerves to send signals, causing weakness in muscles of extremities, tingling and numbness, fatigue, painful parasthesias, loss of reflexes, etc. The weakness in the limbs is usually symmetrical. The symptoms last for more than two months when it is labelled clinically as C.I.D.P ${ }^{2}$. There is considerable variability in progress of the disease.
Some patients experience chronic progressive course, while particularly in younger subjects, have relapsing and remitting course ${ }^{3}$. There is a school of thought that it is the counterpart of Guillain Barre Syndrome in chronic form, though it remains a distinct entity. It can affect any age, sex but observed more in young adults and males are more commonly affected ${ }^{2}$. R S. Laughlin et al reported the incidence of the disease as 1.6/ 100,000 population and prevalence as 8.9/ 100000 population ${ }^{4}$. There are many researchers who reported prevalence of C.I.D.P. as 1-7.7/ 100000 population ${ }^{4,5.6}$. The aetiology is still unknown but 
it is considered as a form of Auto-immune disease $^{7}$.

There is no specific treatment but glucocorticosteroids are commonly used with encouraging results, but cannot be used for longer period due to its side effects. Plasma Exchange (Plasma pheresis) is tried with encouraging results. Stem cell therapy ${ }^{8}$, and Immunotherapy by Intravenous Immunoglobulins ${ }^{9}$ has been tried but with variable results.

\section{Case History}

This 66 year old male patient was reported to be a case of C.I.D.P. since Feb 2018, when he was admitted in one private medical college hospital in Pune on 24.2.2018 for 2 weeks.

NCS/EMG report dated 25 2.2018: Motor and sensory nerve conduction studies were carried out in both upper and lower extremities. Distal Latency prolonged in all motor nerves and reduction of amplitude of Compound Muscle Action Potential in lower limbs. F waves were prolonged in upper limb and not recordable in lower limbs. Motor nerve conduction velocities were reduced to $<70 \%$ of normal. Sensory Nerve Action Potential (SNAP) were absent in both upper and lower limbs.

He was diagnosed as a case of C.I.D.P. and was placed on corticosteroid therapy. During this treatment he was detected with diabetes mellitus type 2. There was no improvement in his clinical condition; he came to Medicine ward by walking on his feet but when he was discharged against medical advice, he was in bed ridden state. The clinical condition of the patient remained the same at home and was admitted in to the Medicine department of Sassoon General Hospital, the teaching hospital of B.J. Medical College, Pune on 15.5.2018 with the complaints of inability to walk, tingling and numbness over limbs, reduced movements and pain in bilateral Upper and lower limbs.

On admission: His Pulse-86/min, B.P.-110/70 mm $\mathrm{Hg}$, Other systems normal.
C.N.S.: Deep tendon reflexes totally absent. Muscle power was grade 1 in upper limbs and similar grade 1 in lower limbs. Hyperaesthesia noted.

Investigations: $\mathrm{Hb}-14.4 \mathrm{~g} \%$, Platelets-2,47,000; WBC-11,700; MCV-83.7

Serum Creatinine-1.1 mg; Blood urea-44, Na-132, K-3.4, SGPT-21, SGOT-57, Total Proteins-6.2, Albumin-2.9; Calcium-10.7 mg. Pt. was A +ve. $\mathrm{He}$ was negative for HIV, HBsAG, HBC, Syphilis, Malaria and was fit for plasma exchange. Treatment:-Patient was treated with Plasmapheresis by exchanging 2 -2.5 lit plasma with 8 bottles of Fresh Frozen Plasma 3 times/week (4 hour session) for 6 weeks. Thus patient received 144 bottles of FFP during 6 weeks.

Inj Vitctofol C in 100 cc N.S OD.,

Tab MV-BC BD;

Tab Rantac BD,

Tab Pregabalin 75mg BD,

Tab Metformin $500 \mathrm{mg}$ TDS,

Tab Glimepiride $1 \mathrm{mg}$ BD.

Physiotherapy was also tried but there was no improvement.

There was no improvement in his clinical condition. The son of the patient expressed the minimum expectation from the treating physician that his father should be able to take care of himself and able to perform basic functions without support from anyone, but the treating physician expressed his opinion that, it was beyond his capacity. He informed that nothing more can be offered to by modern medicine. The condition of patient deteriorated further forcing the patient to take discharge against medical advice on 28.6.2018. During this period Pt. had spent more than Rs 1.25 lacs (much less due to discount given to him in Govt. hospital on account of being a senior citizen) on his treatment but found no improvement in his clinical condition. Patient expressed his willingness for his transfer to Ayurved Research Department for further treatment but unfortunately such request was denied, probably due to misconceptions about 
ability of Ayurved and unawareness about the strength of Ayurved in treating such auto-immune diseases.

He was brought to Ayurvedic ward on stretcher on 12.7.2018 and was admitted on the same day.

On admission to Ayurvedic ward, his clinical condition was as under:

Patient complained of inability to move, tingling and numbness over both upper and lower limbs. Arthalgia in knees. Low appetite; constipated; Sleep disturbed;

Occupation: Earlier he worked in a cotton factory in afternoon/ night shifts for 30 years and retired in the year 2002. He shifted to farming after the retirement and it was revealed that he used to work in the waterlogged farm for 12 hours daily.

Vihar/ Habits: He had habit of tobacco-chewing for last 50 years but stopped it recently.

Aahar/ Diet- Abhshandhi aahar- used to have Idly/ Dosa fermented products and milk everyday at breakfast. He regularly used to consume curd/yoghurt during dinner.

Clinical exam: Pulse-68/min; B.P. 120/80 mm $\mathrm{Hg}$;

Muscle power- Muscle power 1 in both upper and lower extremities (only flicker, no movement). He was unable to move limbs. Only movements of eyelids and eating while lying in bed were only possible. Deep tendon reflexes were totally absent. Investigations: Serum Creatinine $-0.5 \mathrm{mg} / \mathrm{dL}$, Blood urea-14 mg/dL; Uric acid $5.7 \mathrm{mg} / \mathrm{dL}$; Serum Bilirubin-Total $0.39 \mathrm{mg} / \mathrm{dL}$; Direct-0.13 mg/dL;SGPT-21 U/L, SGOT-65 U/L; Serum proteins-6.13 g/L; Alkaline phosphatase-63 U/L. C.S.F. for proteins $-110 \mathrm{mg} / \mathrm{dL}$

$\mathrm{Na}^{+}-145$ meq; $\mathrm{K}^{+;}-5.1$ meq; Random Glucose$160 \mathrm{mg} / \mathrm{dL} ; \mathrm{WBC}-9400 / \mathrm{ccm}, \mathrm{RBC}-4.23$ lakhs/ ccm; Platelets-3,71,000; $\mathrm{Hb}-12$ gm/dL; Hematocrit-27.9 Urine RE- Albumin +

Details of Ayurvedic treatment

\begin{tabular}{|c|c|c|}
\hline Type of treatment & Treatment period & Intervention \\
\hline \multirow[t]{5}{*}{ Systemic treatment } & 13.7.2018 to 3.9 .2018 & $\begin{array}{l}\text { Sitopaladi + Avipatikar choorna } 5 \text { gm BD before meal } \\
\text { along with warm water }\end{array}$ \\
\hline & $\begin{array}{l}\text { 19.7.2018 to } 3.9 .2018 \text { (except } \\
\text { 7.8.2018 to } 11.8 .2018 \text { when } \\
\text { patient had fever) }\end{array}$ & $\begin{array}{l}\text { Devdar } 25 \text { gm + Ashwagandha } 25 \text { gm + Kavachbeej } \\
25 \text { gm + + Guduchi } 25 \text { gm }+ \text { Gokshur } 25 \text { gm + Bala } \\
25 \text { gm+ Raupya bhasma } 2.5 \text { gm and make } 100 \text { parts } \\
\text { of it and one part to be taken along with } \\
\text { Dashamularistha } 2 \text { TSF+ Maharasnadi Kadha } 2 \text { TSF } \\
\text { twice BD with equal quantity of warm water after } \\
\text { meal }\end{array}$ \\
\hline & $\begin{array}{l}\text { 13.7.2018 to } 20.7 .2018 \\
\text { 21.7.2018 to } 3.9 .2018 \text { (except } \\
\text { 7.8.2018 to } 11.8 .2018 \text { when } \\
\text { patient had fever) }\end{array}$ & $\begin{array}{l}\text { Tab Suvarna sutashekhar rasa (Baidyanath) 1BD after } \\
\text { meal } \\
\text { Tab Suvarna sutashekhar rasa 1 OD } \\
\text { Tab Brihatvat chintamani 1 OD }\end{array}$ \\
\hline & 14.7.2018 to 18.7 .2018 & Adulsa + Yastimadhu quath $25 \mathrm{ml}$ daily \\
\hline & 7.8 .2018 to 11.8 .2018 & Mahasudarshan kadha for treating fever and coryza \\
\hline \multirow[t]{3}{*}{$\begin{array}{l}\text { Panchakarma procedures: with } \\
\text { Poorva karma Snehan, Swedan; } \\
\text { Udvartan; Sarvang Pind-sweda; } \\
\text { followed by Yogbasti (Niruha \& } \\
\text { Anuvasan(Matra basti) A/D) per } \\
\text { rectally }\end{array}$} & 17.7.2018 to 24.7 .2018 & $\begin{array}{l}\text { Snehan- Balaguduchyadi/Narayan tail } \\
\text { followed by Udvartan by Vacha \& Triphala; } \\
\text { Followed by Pindsweda : Rice }+ \text { Udad dal + Black } \\
\text { sesame seeds cooked in Quath made up of Deodar }+ \\
\text { Ashwagandha+ Dashamool+ Kavach beej } \\
\text { Niruh: Dashmool+ Erandmool +Punarnava quath } \\
\text { Saidhav salt } 3 \text { gm+ Madhu (Honey) } 5 \mathrm{ml} \text { Narayan } \\
\text { tail } 20 \mathrm{ml} \text {-Total quantity } 400 \mathrm{ml} \text {. } \\
\text { Anuvasan/Matra Basti :Sahchar tail 40ml and } \\
\text { Narayan tail+ Balagudichyadi tail } 40 \mathrm{mlA} / \mathrm{D}\end{array}$ \\
\hline & $\begin{array}{l}\text { 17.7.2018 to } 21.7 .2018 \\
\text { (except 7.8.2018 to } 11.8 .2018 \\
\text { when patient had fever) }\end{array}$ & Nasya by Shadbindu tail for 5 days \\
\hline & 22.7 .2018 to 3.9 .2018 & $\begin{array}{l}\text { Nasya by Panchendriya vardhan tail and Kshirbala tail } \\
\text { A/D }\end{array}$ \\
\hline
\end{tabular}




\begin{tabular}{|c|c|c|}
\hline Nasya & $\begin{array}{l}25.7 .2018 \text { to } 18.8 .2018 \\
\text { (except } 7.8 .2018 \text { to } 11.8 .2018 \\
\text { when patient had fever) }\end{array}$ & $\begin{array}{l}\text { A cycle of } 3 \text { days starting First day Niruh, second day } \\
\text { Majjabasti \& Third day Matra basti (Dashmool } \\
\text { tail/Dhanvantar tail) } 40 \mathrm{ml} \text { in this order for } 7 \text { cycles }\end{array}$ \\
\hline Majja Basti & $\begin{array}{l}\text { 2.8.2018 to } 6.8 .2018 \\
12.8 .2018 \text { to } 18.9 .2018\end{array}$ & By Sahachar tail A/D followed by Dashmool tail \\
\hline Merudand basti & 25.7.2018 to 3.8 .2018 & Sahchar/ Balaguduchyadi tail \\
\hline Virechan & $\begin{array}{l}\text { 13.7.2018 to } 19.7 .2018 \\
27.8 .2018 \text { to } 2.9 .2018\end{array}$ & $\begin{array}{l}\text { Sunthi+ Gokshur kadha } 50 \mathrm{ml}+\text { Erand tail } 5 \mathrm{ml} \\
\text { Aragvadh /Bahava magaj fant } 100 \mathrm{ml} \text { apankali/early } \\
\text { morning }\end{array}$ \\
\hline Pranayam with Omkar & 30.7 .2018 to 3.9 .2018 & Anulom-Vilom \& Omkar chanting \\
\hline \multirow[t]{2}{*}{ Physiotherapy } & 25.7 .2018 to 3.9 .2018 & $\begin{array}{l}\text { Acive Range of Motion for upper limb; Hip and knee } \\
\text { flexion exercise; Ankle-toes movements Hip } \\
\text { abduction, hip extension }\end{array}$ \\
\hline & 16.8 .2018 to 3.9 .2018 & $\begin{array}{l}\text { Walker support; Thoracic expansion exercises; UE } \\
\text { strengthening exercises }\end{array}$ \\
\hline
\end{tabular}

1. Plasmapheresis in Sassoon hospital, Pune

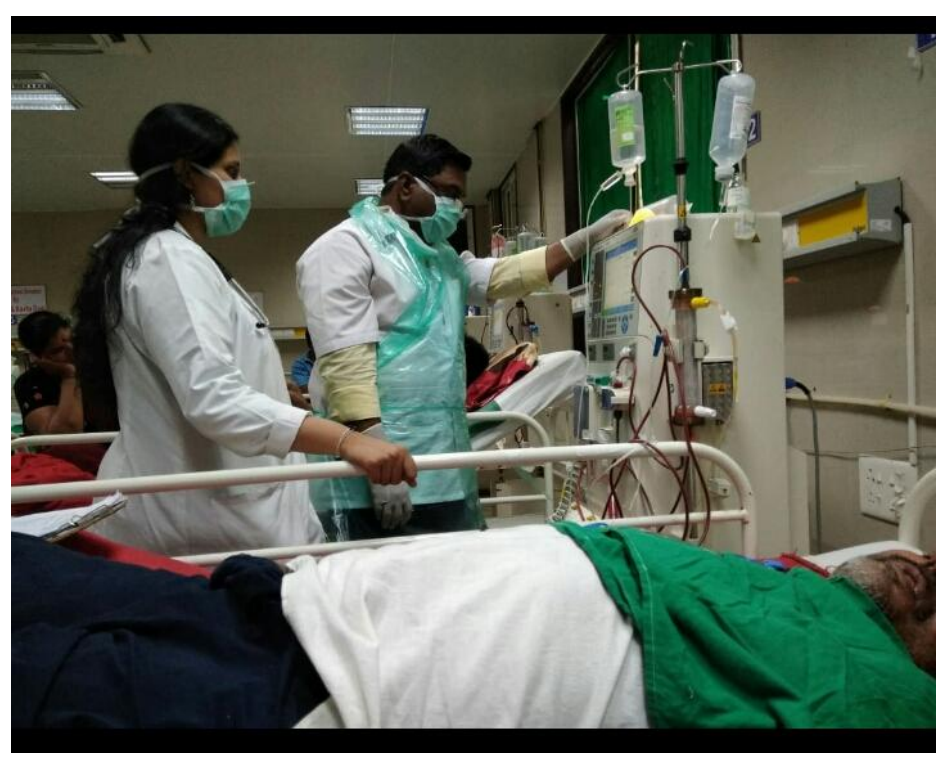

2.During Ayurvedic treatment

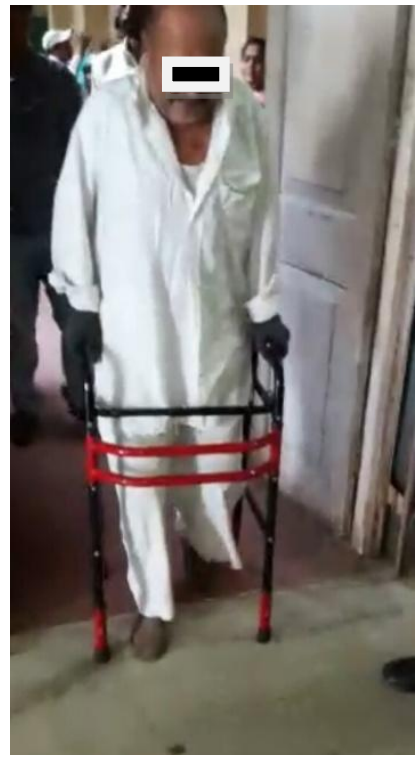

3. Six month follow up of CIDP patient

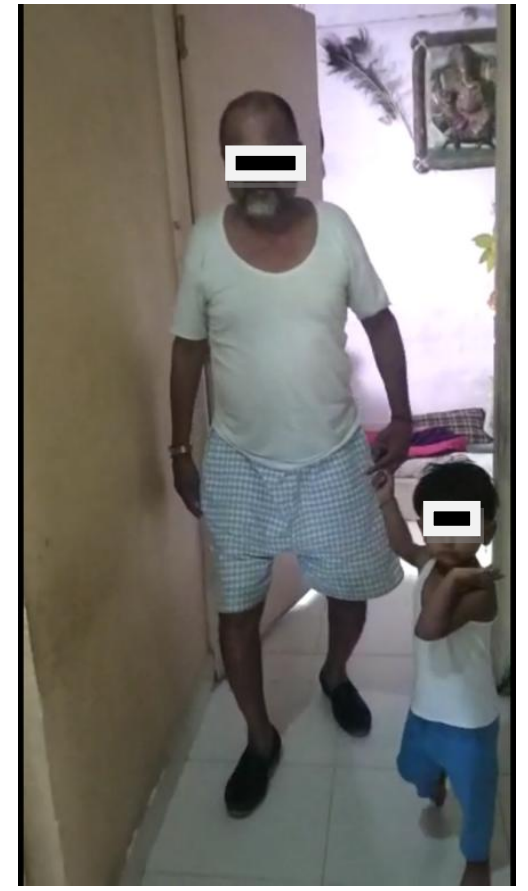




\section{Discussion}

C.I.D.P. is an auto-immune disorder affecting the nerves and nerve roots. Myelin sheath is the protective covering of the axon and any damage to the myelin sheath due to abnormal immune response against substances and tissues normally present in the body, leads to C.I.D.P. Autoimmune diseases like Multiple sclerosis, Guillain Barre syndrome, Myasthenia gravis, C.I.D.P. etc are known in Ayurved as Aam -Vat. Free radicals and Reactive Oxygen Species (R.O.S.) are unstable molecules as a by-product of cellular metabolism and when produced in large amount, it may cause extensive damage to various cells. Aam may be termed as the combination of free radical damaged physiochemical and cellular material, accumulated due to various internal and external toxic stimuli. In the present case the patient was constantly engaged in farming in waterlogged areas 12 hours every day. This was a triggering factor which vitiated the Kapha and Vata due to its sheet and Drava guna. Further diabetes was detected in the patient when symptoms of present illness occurred. We never know how long diabetes was remained undiagnosed.

Vayu is called as Tantra-Yantra dhar. It has complete control over all physiological activities $\&$ it takes part in to all kriyas in the body. Any derangement in function of any organ is due to vitiated Vayu/Vat (Cha. Su. 12/8). This disorder occurs due to Kaphavrutta Vata. Vat vriddhi in Kapha sthan occurs due to Ati-sevan of Rukshadi aahar, Adhyashan, Mal-Mutradi Vegavrodh, Atishram, Anil sevan, living in sheet/ humid climate leads to vitiated vat which combines with Kapha, causing the pathogenesis of this disorder.

\section{Samprapti of Strotorodh pradhan Vatvyadhi}

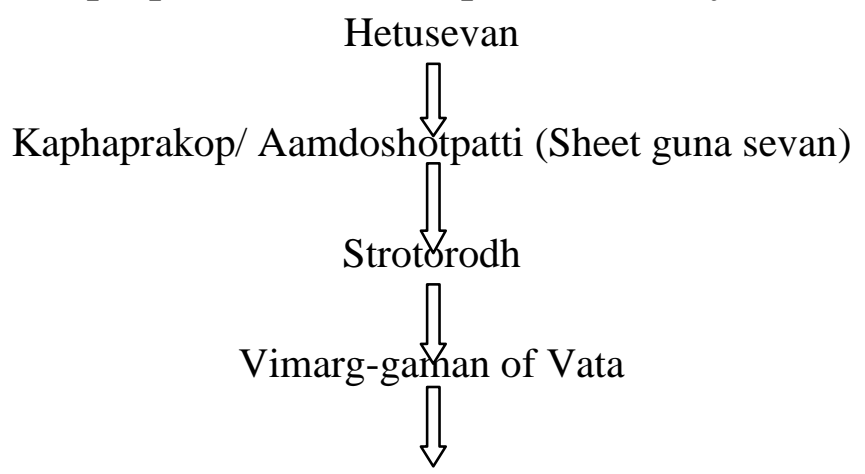

Sthansanshray of Samvayu at Strotovaigunya

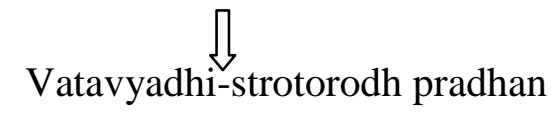
Strotorodh Balbhransh Gaurav Anilmudhata I Alasya apakti nisthiv Malsangh Aruchi Klam: II Vag.Su 13/23-24

Strotorodh is caused by (Ruddha) obstruction in Mal mutradi \& all the micro \& macro strotas in the body, the circulation and function is affected in Annamarg, Mutra marg, Circulatory, Lymphatic, Nervous system marg and all other systems of body. It also adversely affects poshya dhatu nirmiti.

In the present case, patient used to have fermented food like Idly/ Medu vada, Dosa followed by glass of milk and consumption of curd at night that resulted in to Abhishyandhi with viruddha aahar ${ }^{10}$ leading to inflammation at molecular level. In terms of Ayurveda, there was vitiation of Kapha and formation of excessive Kleda which is called as Aam, that produced Aagnimandya. Earlier patient was working in a cotton factory, which caused Pranvahstrotas dushti. Ati-shram/ excessive exertion and Ratro jagran/ wakefulness in night caused Vat-prakop. That also led to Mandagni. Further, patient had diabetes for unknown period; due to the same Shaithilya of Mauns and Meda dhatu was produced.

\section{Chikitsa}

- This disorder is due to Aam related pathogenesis, therefore it is crucial to treat Aam at Jathragni level and at Dhatvagni/ tissue level, following which, we have to put forward disease specific therapy and rejuvenating/ Apunarvabhav chikitsa.

- Nidanparivarjan: We asked patient to avoid Abhishyandhi aahar, stopped milk/ milk products (Guru aahar), protected him from cold; advocated Laghu, supachya aahar that created effect of Langhana and then we administered Sitopaladi , Avipatikar choorna and Maharasanadi qwath to kindle Deepan and Pachan. 
- We carried out Vat chikitsa, to treat vitiated Vata by Snehan-Swedan, Merudand basti followed by Yog basti (Niruh and Anuvasan-Matra basti). As the disease pathology is related to nervous system and Charakacharya remarked that Sneho anilam hanti mrudu karoti deham, Malanam vinihanti Sangam ${ }^{11}$. Granthakaras have remarked that Basti chikitsa is the half chikitsa in Vata disorders. Further in Marmaghat also Basti Chikitsa is very effective. In this case Prakop of Vata occurred due to strotorodh, therefore we decided to remove strotorodh first and then administered Anuloman chikitsa following Deepan - Pachan and Yog basti.

- Vagbhat mentioned - 'Nasa hi shirso dwaram' and Nasya nourishes Uttamang (Vital organs), increases Indriya bala and Manobala and reduces Sanchit doshas; we performed Nasya karma as it digests Kapha and Aam directing the Vatanuloman in proper manner.

- Devdar (Cedrus deodar), Ashwagandha (Withania somniphera), Kavachbeej (Mucuna prurience), Guduchi (Tinospora cordifolia), Gokshur (Tribulus terristeris), Bala (Cida cordifolia) and Raupya bhasma along with Dashamularistha and tab Brihatvat chintamani and Suvarna sootshekhar were aimed as disease specific and Balyaa-Rasayan-Apunarbhav chikitsa of Vata (Majjavahstrotas). We advised patient to perform Anulom-Vilom-a type of Pranayam \& Omkar chanting, that helped to improve the cellular metabolism. Thus Ayurvedic treatment restored the imbalance of Vata and improved microcirculation and carried out repair of myelin sheath, too.

This case is being followed up regularly and patient is completely normal with mobility without any support. There is no relapse. Patient was brought to Ayurvedic ward on stretcher when admitted but was discharged home walking on his feet, without support. This is the ability and strength of Ayurved to restore the function and quality of life in such a critical case of C.I.D.P..

Please see the recent photograph No.3 of 6 month follow-up the patient taking care not only of himself but of granddaughter, too!

\section{Conclusion}

This case study established that Ayurved has ability to treat Auto-immune disorders like C.I.D.P., which is having progressive and protracted course; the progress of disease was not only arrested but pathology of the disease was also reversed. We may conclude that Ayurved therapy is better to modern treatment which is based primarily on steroid/immunosuppressants and plasmapheresis.

\section{Conflict of interest- None}

\section{References}

1. What is Chronic Inflammatory Demyelinating Polyneuropathy (CIDP)? https://www.webmd.com/brain/what-iscidp\#1

2. Chronic Inflammatory Demyelinating Polyneuropathy... https://www.ninds.nih.gov/Disorders/AllDisorders/Chronic-InflammatoryDemyelinating- Polyneuropathy-CIDPInformation-Page

3. Stephan L. Hauser, Anthony A. Amato: Guillain Barre Syndrome and other Immune- Mediated Neuropathies. Chapter No.460 in Harrison's Principles of Internal Medicine Vol.2; Edited by Kasper, Fauci, Hauser, Longo, Jameson and Loscalzo. Mc Graw Hill Education publications. $19^{\text {th }}$ Edition. 2015: 2694-2706.

4. Laughlin RS, Dyck PJ, Melton LJ, , Leibson C, Ransom J, Dyck PJ. Incidence and prevalence of CIDP and the association of diabetes mellitus. Neurology. 2009;73(1) :39-45. [PMC free article] [PubMed] 
5. McCombe PA, Pollard JD, McLeod JG. Chronic inflammatory demyelinating polyradiculoneuropathy. A clinical and electrophysiological study of 92 cases. Brain. 1987;110:1617-30. [PubMed]

6. Holzbauer SM, DeVries AS, Sejvar JJ, et al. Epidemiologic investigation of immune-mediated polyradiculoneuropathy among abattoir workers exposed to porcine brain. PLoS One. 2010;5(3):e9782. [PMC free article] [PubMed]

7. NORD. Chronic Inflammatory Demyelinating Polyneuropathy. https://rarediseases.org/rarediseases/chronic-inflammatorydemyelinating-polyneuropathy/

8. Mazen M. Dimachkie and Richard J. Barohn. Chronic Inflammatory Demyelinating Polyneuropathy. Curr Treat Options Neurol. 2013 Jun; 15(3): 350-366.

9. Intravenous Immunoglobulin. Medscape. Updated on 5 Jul 2018 available from: https://emedicine.medscape.com/article/21 0367-overview\#a2

10. Sabnis M. Viruddha Ahara: A critical view. AYU 2012; Vol 33/3:332-6. Available from http://www.ayujournal.org/text?2012/33/3/ 332/108817

11. Vaidya Jadavji Trikamji Acharya, Editor Charak Samhita by Agnivesa, of Chakrapanidatta. Chaukhamba Publications, New Delhi-110 002. Siddisthan, Chapter 1 verse 7. Reprint 2016. p:384. 